\title{
Quality of Newly Formed Cartilaginous Tissue in Defects of Articular Surface after Transplantation of Mesenchymal Stem Cells in a Composite Scaffold Based on Collagen I with Chitosan Micro- and Nanofibres
}

\author{
A. NEČAs ${ }^{1}$, L. PLÁNKA ${ }^{2}$, R. SRNEC ${ }^{1}$, M. CRHA ${ }^{1}$, J. HLUČILOVÁ ${ }^{3}, J$. KLÍMA ${ }^{3}$,

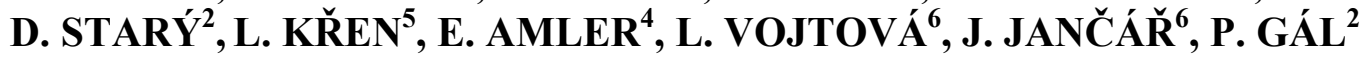

${ }^{1}$ Department of Surgery and Orthopedics, Small Animal Clinic, Faculty of Veterinary Medicine, University of Veterinary and Pharmaceutical Sciences Brno, Czech Republic, ${ }^{2}$ Department of Pediatric Surgery, Orthopedics and Traumatology, Faculty Hospital Brno, Czech Republic, ${ }^{3}$ Institute of Animal Physiology and Genetics of the Academy of Sciences of the Czech Republic, Liběchov, Czech Republic, ${ }^{4}$ Institute of Experimental Medicine of the Academy of Sciences of the Czech Republic, Prague, Czech Republic, ${ }^{5}$ Department of Pathology, Faculty Hospital Brno, Czech Republic, ${ }^{6}$ Institute of Materials Chemistry, University of Technology, Brno, Czech Republic

Received November 25, 2008

Accepted September 21, 2009

On-line November 20, 2009

\section{Summary}

The aim of this study was to evaluate macroscopically, histologically and immunohistochemically the quality of newly formed tissue in iatrogenic defects of articular cartilage of the femur condyle in miniature pigs treated with the clinically used method of microfractures in comparison with the transplantation of a combination of a composite scaffold with allogeneic mesenchymal stem cells (MSCs) or the composite scaffold alone. The newly formed cartilaginous tissue filling the defects of articular cartilage after transplantation of the scaffold with MSCs (Group A) had in $60 \%$ of cases a macroscopically smooth surface. In all lesions after the transplantation of the scaffold alone (Group B) or after the method of microfractures (Group C), erosions/fissures or osteophytes were found on the surface. The results of histological and immunohistochemical examination using the modified scoring system according to O'Driscoll were as follows: $14.7 \pm 3.82$ points after transplantations of the scaffold with MSCs (Group A); $5.3 \pm 2.88$ points after transplantations of the scaffold alone (Group B); and $5.2 \pm 0.64$ points after treatment with microfractures (Group C). The O'Driscoll score in animals of Group A was significantly higher than in animals of Group B or Group $C(p<0.0005$ both). No significant difference was found in the O'Driscoll score between Groups B and C. The treatment of iatrogenic lesions of the articular cartilage surface on the condyles of femur in miniature pigs using transplantation of MSCs in the composite scaffold led to the filling of defects by a tissue of the appearance of hyaline cartilage. Lesions treated by implantation of the scaffold alone or by the method of microfractures were filled with fibrous cartilage with worse macroscopic, histological and immunohistochemial indicators.

\section{Key words}

Bone marrow mesenchymal stem cells • Allogeneic • Micropicking - Articular cartilage

\section{Corresponding author}

A. Nečas, Department of Surgery and Orthopedics, Small Animal Clinic, Faculty of Veterinary Medicine, University of Veterinary and Pharmaceutical Sciences Brno, Palackého 1-3, 61242 Brno, Czech Republic. E-mail: necas@eurosat.cz

\section{Introduction}

The ability of spontaneous regeneration of articular cartilage is rather low. Upon its damage there may be, close to the defect, a short-lived increase of mitotic activity connected with a local increase of 
production of glycosaminoglycans and collagen (Edwards 1967) but in the outcome there is no effective healing of the defect (Mankin 1974). In the case of a more profound defect caused by osteochondral dissection, osteochondral fracture or chronic overloading and degeneration an important role in the mechanisms of healing is played by the effect of mesenchymal elements of the subchondral bone. It participates in a new formation of the connective tissue of fibrous nature, which, however, gradually differentiates into a lower-quality fibrocartilage (Mitchell and Shepard 1976, Shapiro et al. 1993). For this reason the research of healing of articular surface defects centers on the possibility of better repair of damaged cartilage using transplantation of cells (chondrocytes, mesenchymal stem cells) and tissue engineering. Our laboratories focus in recent times on the development and application of biopolymers settled with targetdifferentiated stem cells for healing of diseases of the mobility apparatus that are checked in experimental animals (Gál et al. 2007, Jančář et al. 2007, Koláčná et al. 2007, Plánka et al. 2007, Varga et al. 2007, Nečas et al. 2008).

The aim of this experimental study was the macroscopic, histological and immunohistochemical comparison of healing cartilage lesions, using both classical (and frequently employed clinically) surgical method of microfractures (Detterlibne et al. 2008) with the locally developed transplantation of a combination of composite scaffold with allogeneic mesenchymal stem cells (MSCs). Defects treated by transplantation of the scaffold without MSCs served as control.

\section{Materials and Methods}

The experiments were performed in 40 miniature pigs from a certified breeding at the Institute of Animal Physiology and Genetics of the Academy of Sciences of the Czech Republic at Liběchov. Their age at the time of surgery was 5-7 months, their weight was $18 \pm 4 \mathrm{~kg}$.

The study is part of an experiment employing 20 knee joints of 20 miniature pigs of the Liběchov institute. In 10 animals a total of four iatrogenic defects of the knee joint were formed in the left knee, two on the load area of the joint surface (one on the medial, one on the lateral femur condyle), two on the non-load area of the joint surface (one medially and one laterally in the distal section of sulcus trochlearis ossis femoris). Two of these four defects (load area of the medial femur condyle and non-load area medially in the distal part of sulcus trochlearis ossis femoris) were treated by transplantation of a combination of a composite scaffold with allogeneic mesenchymal stem cells (scaffold + MSCs), two other defects (load area of the lateral femur condyle and nonload area lateral in the distal section of sulcus trochlearis ossis femoris) were treated by transplantation of the composite scaffold without cells (control). In the other 10 miniature pigs a total of four iatrogenic defects of the articular cartilage were formed on the femur of the left knee joint and treated with clinically employed methods of surgical treatment of lesions - abrasive chondroplastics, forage, micropicking and mosaicplasty.

For the purposes of this study each knee joint was evaluated only with respect to the healing of cartilage defects at the load area of the medial and lateral condyle treated in this experiment by the transplantation of mesenchymal stem cells in a composite scaffold developed here (scaffold based on collagen I containing micro- and nanofibers of chitosan), or by control transplantation of the scaffold alone (Groups A and B, respectively). This was compared with healing of cartilage lesion treated by one of the clinically common methods of micropicking (Group C). Group A thus included 10 defects of the knee joint formed in the load area of femur medial condyle and treated by transplantation of a combination of the composite scaffold with allogeneic mesenchymal stem cells (scaffold + MSCs). Group B contained 10 defects of the joint cartilage formed on the load area of the femur lateral condyle and treated by transplantation of the composite scaffold alone without cells (scaffold). Group C contained 10 defects of the joint cartilage treated by micropicking.

Surgical procedures were performed under general anesthesia. Before induction to the anesthesia enrofloxacin (BAYTRIL $2.5 \%$ inj. ad us. vet., Bayer) in a dose of $5 \mathrm{mg} / \mathrm{kg}$ was administered intravenously. Induction was achieved by intramuscular administration of midazolam (1 mg/kg, DORMICUM inj., Roche) + fentanyl $(0.02 \mathrm{mg} / \mathrm{kg}$, FENTANYL, Janssen and medetomidine at a dose of $200 \mu \mathrm{g} / \mathrm{kg}$, DOMITOR inj. a.u.v., Pfizer). Total inhalation anesthesia was then maintained by a mixture of oxygen, nitrous oxide (2:3) and isoflurane (FORANE, Abbott Laboratoires) using a non-rebreathing system (Bain). Heart rate, respiratory rate, invasive blood pressure, end-tidal partial pressure of carbon dioxide and saturation of hemoglobin by oxygen was monitored (DATEX Cardiocap II). As this combination of drugs causes a strong respiratory 
depression, all animals were connected to the controlled ventilation device.

Lateral arthrotomy of the left knee joint was performed aseptically, and in the region of the weightbearing surface of the lateral femoral condyle a defect was drilled using a calibrated 6-mm drill bit through cartilage and subchondral bone into the depth of $12 \mathrm{~mm}$. Into this defect, a scaffold was placed by a press-and-fit method in the shape of a cylinder $8 \mathrm{~mm}$ in diameter and $10 \mathrm{~mm}$ in length, seeded with mesenchymal stem cells (Group A). The same defect was created on the weightbearing surface of the medial femoral condyle and only the scaffold (without MSCs) of the same dimensions was placed in it (Group B). In animals of Group C a circular defect $6 \mathrm{~mm}$ in diameter was created on the weightbearing surface of the lateral femoral condyle using a circular scalpel. After the excision of cartilage, subchondral bone was impaired using the method of microfracture (micropicking).

After the surgery, all three anesthetic components were antagonized using a combination of naloxone $(0.03 \mathrm{mg} / \mathrm{kg}$, INTRENON inj., Léčiva a.s.) + flumazenil $(0.1 \mathrm{mg} / \mathrm{kg}$, ANEXATE, Hoffmann-La Roche Ltd.) + atipamezol (1.0 mg/kg, ANTISEDAN inj. ad us. vet., Pfizer Animal Health) that was administered intramuscularly. Analgesia in the post-operative period was achieved by application of carprofen (RIMADYL inj. ad us. vet., Pfizer Animal Health) at a dose of $2 \mathrm{mg} / \mathrm{kg} /$ day for three days after the surgery. Following recovery from surgery, the animals were allowed to walk freely and weight-bear as tolerated. During the whole study period, the animals were fed, handled and housed according to the principles of welfare. At the end of the experiment (16 weeks after the surgery), all animals were lege artis euthanized. First, they were put under general anesthesia using intravenous thiopental at a dose of $20 \mathrm{mg} / \mathrm{kg}$. Then they were given intravenous T 61 inj. ad us. vet. (Hoechst Roussel Vet.) in a dose of $1 \mathrm{ml}$ pro toto.

The experimental procedure was in full agreement with the ethical norms for animal experiments and after agreement by the Ethical Commission (no. 46613/2003-1020).

\section{Preparation of the stem cells}

The source of the mesenchymal stem cells was the bone marrow blood removed from the wing of the hip bone (Friedenstein et al. 1987, 1996, Kim et al. 2003) of unrelated animals (allogeneic transplantation). The bone marrow blood was aspirated from tuber coxae ala ossis illii (Grande et al. 1995, Guo et al. 2004, Risbud et al. 2006) into a 20-ml syringe with $10 \mathrm{ml}$ Dulbecco's phosphate buffered saline (PBS) with $2 \%$ fetal bovine serum (FBS, StemCell Technologies) and $5 \mathrm{IU}$ heparin $/ \mathrm{ml}$ connected with a bioptic needle. Under sterile conditions, the bone marrow blood (about $20 \mathrm{ml}$ ) was deposited over $15 \mathrm{ml}$ of Ficoll-Paque PLUS (StemCell Technologies). After centrifugation at $400 \mathrm{~g}$ for $30 \mathrm{~min}$ at room temperature, the dense gradient separated erythrocytes and granulocytes as a pellet in the bottom part of the tube. Mononuclear cells were situated in an opalescent layer between Ficoll and blood plasma. This layer was taken out, washed in a culture medium (see below) and used for propagation under in vitro conditions. The average amount of mononuclear cells from each isolation was $60 \times 10^{6}$ cells. Cell number and viability were analyzed on Vi-CELL (Series Cell Viability Analyzers) and about $98 \%$ of viable cells were detected. Cells were seeded in $75-\mathrm{cm}^{2}$ tissue culture plastic flasks at a density of approximately $5 \times 10^{5}$ cells $/ \mathrm{cm}^{2}$ and cultured at $37{ }^{\circ} \mathrm{C}$ in humidified atmosphere with $5 \%$ of $\mathrm{CO}_{2}$. The culture medium was $\alpha$-MEM medium (Gibco) supplemented with $10 \%$ FBS (Sigma Aldrich) and gentamycin (50 mg/ml, Sigma Aldrich). After $24 \mathrm{~h}$ of culture, the non-adherent cells were removed and during the subsequent culture ( 3 weeks) the medium was exchanged every third day. The first colonies of mesenchymal stem cells appeared after 3 days of culture and the $80 \%$ of confluence was achieved after 7 days of culture. Cells were passaged with $0.5 \%$ trypsin-EDTA solution (Sigma Aldrich) for $5 \mathrm{~min}$ at $37^{\circ} \mathrm{C}$ and replated in $150 \mathrm{~cm}^{2}$ tissue culture plastic flasks at a density of 5000-6000 cells $/ \mathrm{cm}^{2}$. The cultivated cells were tested by the commonly used positive MSC markers CD29, CD44, CD90, CD105 (Gao et al. 2007, Jackson et al. 2007) and newly by CD147 (Tisato et al. 2007). The panel of used antibodies was the following: anti-CD29 (clone MEM 101A), anti-CD105 (clone MEM 229), antiCD44 (clone IM7), anti-CD90 (clone 5E10, BD Biosciences, San Jose, CA, USA), anti-CD45 (clone K262-1E4, AbD, Serotec, Kidlington, UK). Every transplantate prepared here contained $3 \times 10^{6} \mathrm{MSCs}$. For labeling with the fluorescent dye CM-DiI (Molecular Probes) at a concentration of $5 \mu \mathrm{g} / 2.5 \mathrm{ml}$ PBS $(2 \mu \mathrm{M})$, cells were harvested on the day of transplantation, incubated for $5 \mathrm{~min}$ at $37^{\circ} \mathrm{C}$ and then for additional $15 \mathrm{~min}$ at $4{ }^{\circ} \mathrm{C}$. At the end of labeling the cells were thoroughly washed in PBS. To induce chondrogenic differentiation (Jorgensen et al. 2001, Miura et al. 2002, 
Gao et al. 2007), the labeled cells were placed in the differentiation medium composed of $\alpha$-MEM supplemented with $100 \mathrm{ng} / \mathrm{ml}$ recombinant human TGF $\beta_{1} \quad$ (R\&D Systems), $\quad 100 \quad \mathrm{nM}$ dexamethasone (Medochemie), $50 \mu \mathrm{g} / \mathrm{ml} \mathrm{L-ascorbic} \mathrm{acid} \mathrm{2-phosphate}$ (Sigma Aldrich), $1 \%$ insulin-transferrin-selenium A (Gibco) for $30 \mathrm{~min}$. Subsequently, the cells were centrifuged at $700 \mathrm{~g}$ for $5 \mathrm{~min}$, and cell pellets were prepared for their deposition into a scaffold. $3 \times 10^{6}$ predifferentiated cells were subsequently pelleted on porous cylinder fitted close to 96 -well plate at $100 \mathrm{~g}$ for $20 \mathrm{~min}$. Subsequently, the culture medium was added and the scaffolds were placed in an incubator with a humidified atmosphere, $5 \% \mathrm{CO}_{2}$ at $37{ }^{\circ} \mathrm{C}$ and implanted on the next day.

\section{Scaffold}

The scaffolds used had the form of a porous cylinder (pores of about $100 \mu \mathrm{m}$ ) containing $0.5 \%$ collagen and $30 \%$ chitosan netted with EDC (1-ethyl-3(3-dimethylaminopropyl)carbodiimide hydrochloride) and catalyzed with NHS (98\% N-hydroxysuccinimide), with a structure of chitosan nanofibers.

\section{Histological evaluation}

Histological examinations were carried out at the Institute of Pathology of the Faculty Hospital in Brno. The basic stain used for the preparations was hematoxylin-eosin for an overview of tissues in the whole preparation. For checking the presence of extracellular matrix in the hyaline cartilage special staining with periodic acid-Schiff (PAS) was used (detection of neutral and acidic mucopolysaccharides which are components of the intercellular material of the hyaline cartilage) and immunohistochemical staining with an antibody against collagen type II (collagen type in the hyaline articular tissue). Immunohistochemical analysis was performed on formalin-fixed, paraffin-embedded, trypsin-digested $4 \mu \mathrm{m}$ thick tissue sections. Collagen II (Novocastra, rabbit polyclonal) primary antibody with dilution of 1:30 was used for $60 \mathrm{~min}$ incubation at $25^{\circ} \mathrm{C}$. Standard indirect avidin biotin diaminobenzidin detection (ABC/DAB) technique was used to visualize the type II collagen followed by a counterstain with hematoxylin. Mature cartilage (away from the defect) was used as internal positive control. Staining patterns in experimental and control regions were identical, it corresponded to mature cartilage. Healing of the defects was estimated macroscopically. For an objective histological evaluation
(Table 1) we used a modified scheme according to O'Driscoll et al. (1988) and Guo et al. (2004), which combines the results of histological and immunohistochemical examination. Our modification consisted in replacing special staining with safranin $O$ by the PAS stain. The origin of the chondrocytes found in the articular cartilage defect was confirmed by immunofluorescence detection of the CM-DiL stain.

Table 1. Modified (PAS stain) scheme of histological and colorimetric scoring according to O'Driscoll et al. (1988).

\section{Cell morphology}

Hyaline articular cartilage $\quad 4$

Incompletely differentiated mesenchyme 2

Fibrous tissue or bone $\quad 0$

\section{PAS staining of the matrix}

Normal or nearly normal 3

Moderate 2

Slight 1

None $\quad 0$

Surface regularity

Smooth and intact 3

Superficial horizontal lamination $\quad 2$

Fissures $-25-100 \%$ of the thickness 1

Severe disruption. including fibrillation $\quad 0$

Structural integrity

Normal 2

Slight disruption. including cysts 1

Severe disintegration 0

\section{Thickness}

$100 \%$ of normal adjacent cartilage 2

$50-100 \%$ of normal cartilage 1

$0-50 \%$ of normal cartilage 0

Bonding to the adjacent cartilage

Bonded at both ends of graft 2

Bonded at one end, or partially at both ends 1

Not bonded 0

Hypocellularity

Normal cellularity 3

Slight hypocellularity $\quad 2$

Moderate hypocellularity 1

Severe hypocellularity $\quad 0$

Chondrocyte clustering

No clusters $\quad 2$

$<25 \%$ of the cells 1

$25-100 \%$ of the cells $\quad 0$

Freedom from degenerative changes in adjacent cartilage

Normal cellularity. no clusters, normal staining 3

Normal cellularity, mild clusters, moderate staining 2

Mild or moderate hypocellularity, slight staining 1

Severe hypocellularity. poor or no staining 0 
Table 2. Results of macroscopic evaluation of the surface of newly formed tissue filling the iatrogenic defect of articular cartilage (relative frequency in \%).

\begin{tabular}{lccc}
\hline Macroscopic evaluation & $\begin{array}{c}\text { Group A } \\
\text { (transplantation of scaffold } \\
+ \text { MSCs) }\end{array}$ & $\begin{array}{c}\text { Group B } \\
\text { (transplantation of } \\
\text { scaffold) }\end{array}$ & $\begin{array}{c}\text { Group C } \\
\text { (micropicking) }\end{array}$ \\
\hline $\begin{array}{l}\text { Smooth surface } \\
\text { Surface erosion/fissure } \\
\text { or osteophytes }\end{array}$ & 60 & 0 & 0 \\
\hline
\end{tabular}

Table 3. Results of immunohistochemical and immunofluorescence examinations of tissue samples taken from the iatrogenic cartilage defects treated by scaffold transplantation with MSCs, scaffold alone (control) or the micropicking method.

\begin{tabular}{|c|c|c|c|c|c|c|c|c|c|c|c|c|c|}
\hline \multirow[t]{2}{*}{ Animal } & \multicolumn{4}{|c|}{$\begin{array}{c}\text { Group A } \\
\text { (transplantation of } \\
\text { scaffold + MSCs) } \\
\text { Ten tissue samples }\end{array}$} & \multicolumn{4}{|c|}{$\begin{array}{c}\text { Group B } \\
\text { (transplantation of } \\
\text { scaffold) } \\
\text { Ten tissue samples }\end{array}$} & \multirow[t]{2}{*}{ Animal } & \multicolumn{4}{|c|}{$\begin{array}{c}\text { Group C } \\
\text { (micropicking) } \\
\text { Ten tissue samples }\end{array}$} \\
\hline & & PAS & IHC & IFS & & PAS & $\mathrm{IHC}$ & IFS & & & PAS & IHC & IFS \\
\hline F 125 & 15 & + & +++ & + & 4 & - & + & - & E 56 & 5 & - & + & - \\
\hline F 186 & 14 & + & +++ & + & 5 & - & + & - & F 60 & 4 & - & + & - \\
\hline F 185 & 13 & + & ++ & - & 6 & + & ++ & - & E 11 & 3 & - & + & - \\
\hline F 127 & 16 & + & +++ & + & 7 & - & + & - & F 70 & 5 & - & ++ & - \\
\hline F 197 & 18 & + & +++ & + & 5 & - & ++ & - & E 52 & 6 & - & + & - \\
\hline F 139 & 14 & + & +++ & + & 4 & - & + & - & F 71 & 5 & - & ++ & - \\
\hline F 196 & 13 & + & ++ & + & 6 & - & + & - & F 28 & 6 & - & + & - \\
\hline F 126 & 15 & + & +++ & + & 5 & + & + & - & F82 & 7 & - & + & - \\
\hline F 187 & 14 & + & +++ & + & 6 & - & + & - & F84 & 7 & - & + & - \\
\hline F 188 & 15 & - & + & - & 5 & - & + & - & E75 & 4 & - & + & - \\
\hline
\end{tabular}

PAS: - without neutral and acidic mucopolysaccharides

+ presence of neutral and acidic mucopolysacchrides in the newly formed cartilage

IHC: - immunohistochemical detection of collagen II, i.e. collagen is not detectable

+ immunohistochemical detection of collagen II, i.e. collagen is detectable

IFS: - in a fluorescence microscope the IF stain is not bound to the $\mathrm{CHC}$ membrane

+ in a fluorescence microscope the IF stain is bound to the $\mathrm{CHC}$ membrane

\section{Statistical analysis}

For evaluation of the quantitative parameter (O’Driscoll score) Steel-Dwass Test-Nonparametric Multiple Comparisons was used; for statistical evaluation of qualitative parameters (IHS, IFS, COL) Fisher Exact Probability Test was used.

\section{Results}

The newly formed cartilaginous tissue filling the defects of the articular cartilage after scaffold transplantation with MSCs (Group A) displayed in $60 \%$ cases a macroscopically smooth surface, where $40 \%$ of the treated lesions had on their surface macroscopically observable erosions/fissures, or osteophytes (Table 2). In all the defects treated by transplantation of the scaffold alone (Group B) or in defects treated by micropicking (Group C) all the lesions filled with newly formed tissue showed on their surface macroscopically visible erosions/fissures or osteophytes (Table 2).

The results of histological and immunohistochemical examination of newly formed cartilaginous tissues using a modified classification according to O'Driscoll et al. (1988) showed the following means: $14.7 \pm 3.82$ points for samples of newly formed cartilage after transplantation of scaffold with MSCs (Group A) 


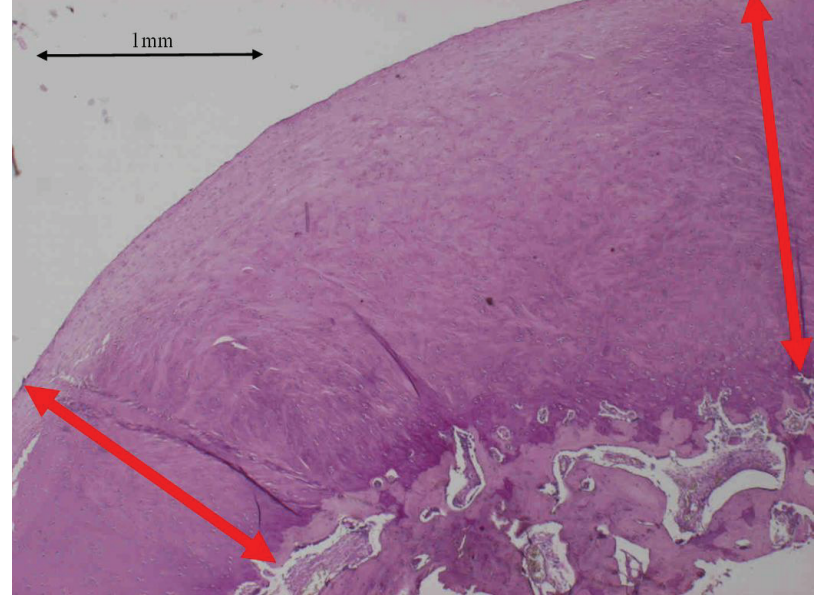

Fig. 1. Hyaline-like cartilage in the healed articular surface defect (arrows) after transplantation of scaffold seeded with MSCs (Group A, PAS stain, original magnification $\times 40$ ).

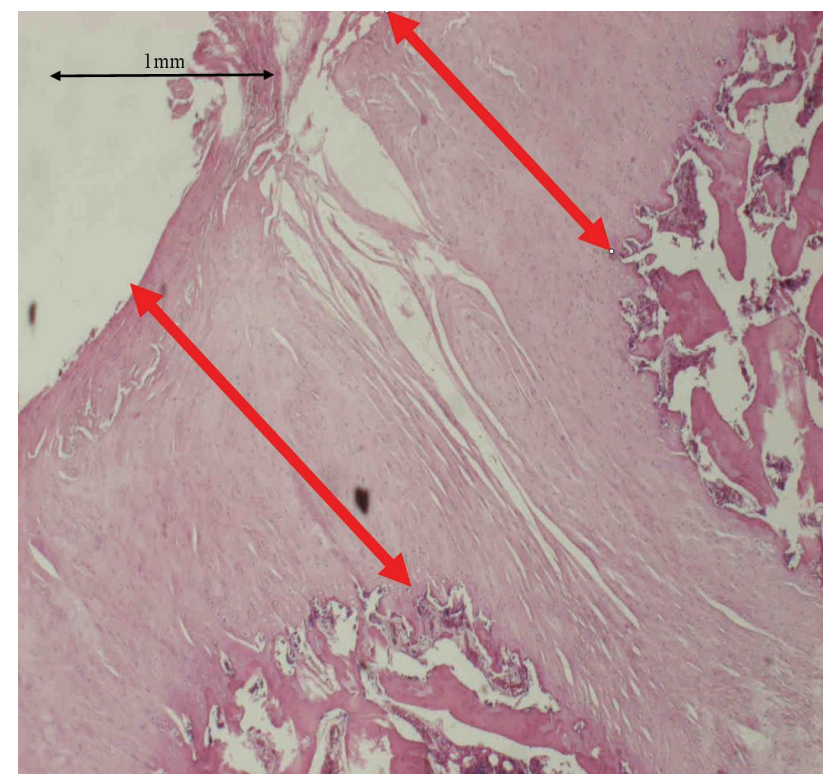

Fig. 2. Articular cartilage defect healed with fibrous cartilage (arrows) after transplantation of scaffold without MSCs (Group B, haematoxylin-eosin, original magnification $\times 40$ ).

(Fig. 1), 5.3 \pm 2.88 points for transplantations of scaffold alone (Group B) (Fig. 2) and 5.2 \pm 0.64 points for defects treated by micropicking (Group C) (Fig. 3). The O'Driscol score was significantly higher in animals of Group A than in animals of Group B $(p=0.0004016)$ and Group C $(p=0.0004208)$. No significant difference was found in the $\mathrm{O}^{\prime}$ Driscol score between Groups B and C.

Table 3 shows the results of immunohistochemical and immunofluorescence examinations of tissue samples filling the individual lesions of the joint surface (Fig. 4). In fact, in every case (microfracture included) there was the light positivity of Collagen II Ab (Fig. 5). The results of Collagen II Ab

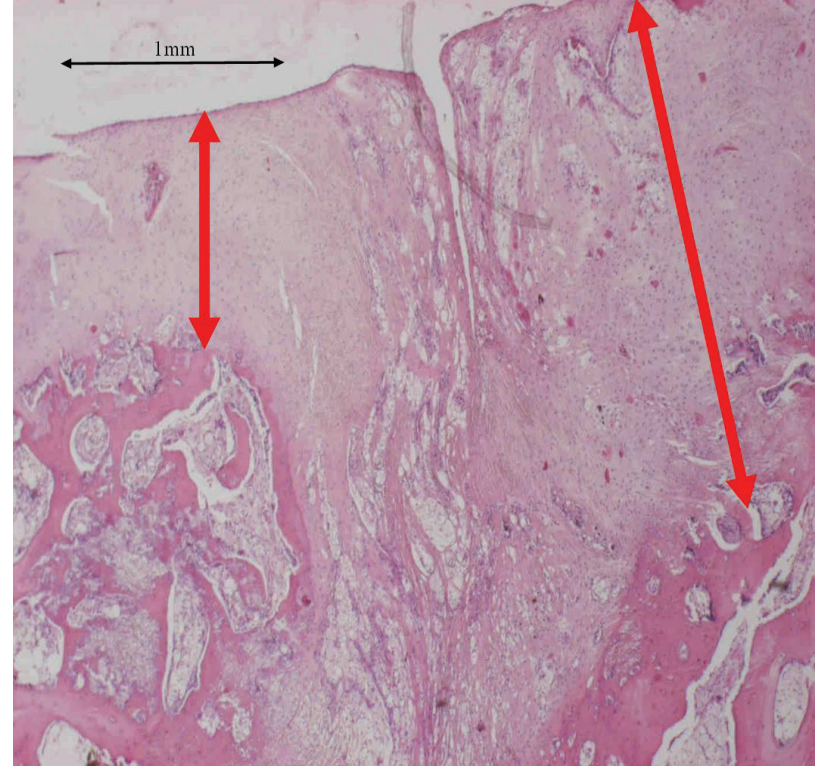

Fig. 3. Cartilage defect (arrows) healed with fibrous cartilage after micropicking (Group C, haematoxylin-eosin, original magnification $\times 40$ ).

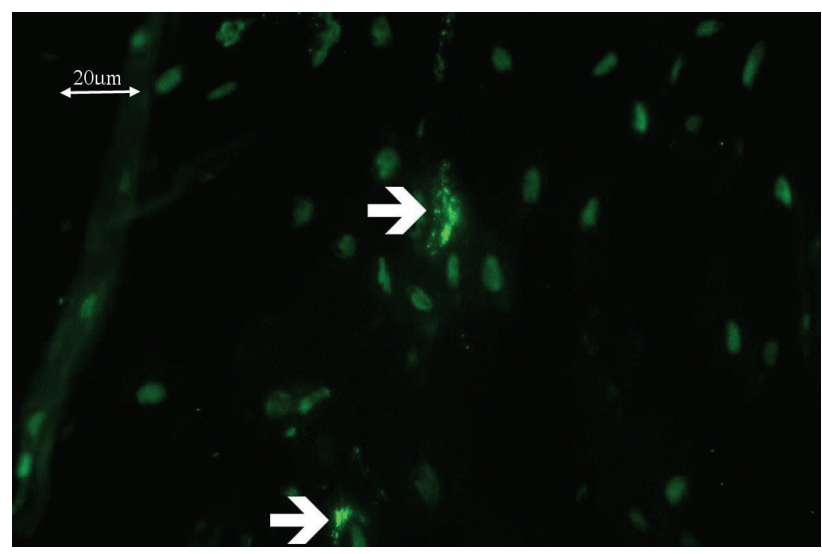

Fig. 4. CM-DiI labeled cells (arrows) detected using an immunofluorescence microscope in the newly formed cartilage (original magnification $\times$ 400).

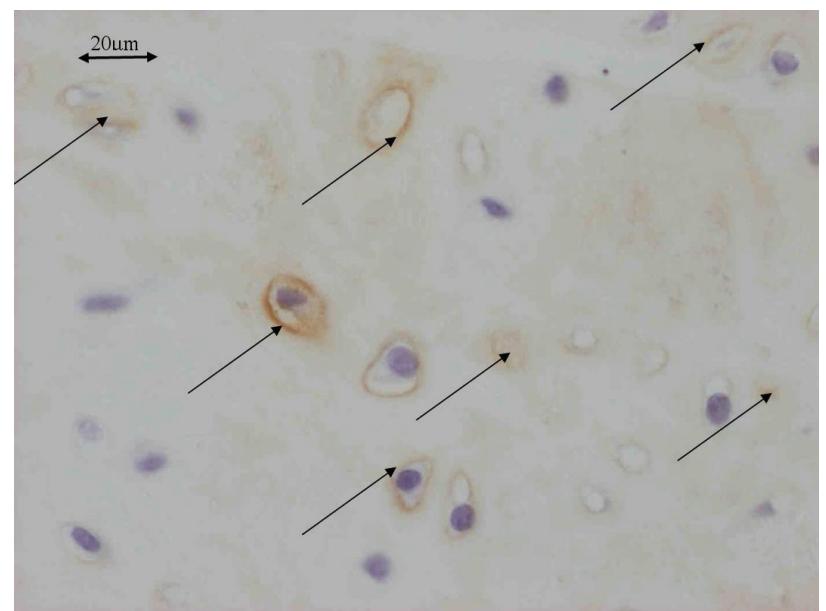

Fig. 5. Immunohistochemical type-II collagen detection (arrows), original magnification $\times 400$. 
analysis were separated into three degrees $(+$ light positivity, ++ medium positivity, +++ strong positivity). There is significantly stronger positivity of Collagen II $\mathrm{Ab}$ in Group $\mathrm{A}$ than in the defects treated by transplantation of the scaffold alone (Group B, $\mathrm{p}=0.00018$ ) as well as in defects treated by micropicking (Group C, $\mathrm{p}=0.00018$ ) (Table 3). The immunofluorescent stain CM-DiI was detected in Group A on $89 \%$ samples of newly formed cartilage, while in Groups B and C the immunofluorescence was always absent $(\mathrm{p}=0.00018)$.

\section{Discussion}

Injuries and degenerative processes of articular cartilage represent some of the most frequent diseases of the musculoskeletal system and belong to the most intensely studied medical problems (Grande et al. 1995, Gao et al. 2007). The articular cartilage is a highly differentiated tissue without blood vessels, and its cells are displaying a low mitotic activity. Possibilities of treating the defects of articular cartilage are being extended, with tissue engineering playing here an important role (Langer et al. 1993, Butler et al. 2004). The first cell transplantate for the defects of articular cartilage were autologous chondrocytes which gave promising results (Brittberg et al. 1994, Chu et al. 1999). In view of the use of the periostal lobe to cover the cartilage defect even here one cannot exclude the effects of progenitor cells. Moreover, the method requires the application of patient's own tissue for the graft cultivation. The market now offers commercial technologies to prepare suspensions of autologous chondrocytes in a scaffold that can be introduced by different techniques into the articular cartilage defect $\left(\right.$ Chondron $\left.{ }^{\mathrm{TM}}\right)$. At present the main interest is attracted by the possibility of using stem cells (Grande et al. 1995, Guo et al. 2004, Hannouche et al. 2007).

Most studies on animal models deal with rabbits (Wakitani et al. 1994, Grande et al. 1995, Hannouche et al. 2007), rats (Lucas et al. 1995) or sheep (Guo et al. 2004, Hoemann et al. 2005). In the present experiment we used a miniature pig to approach most closely the size and biomechanics of humans. The removal and treatment of stem cells was carried out in the cytological laboratory of the Institute of Animal Physiology and Genetics at Liběchov. The differentiation protocol of incubations in a medium with TGF- $\beta 1$ and dexamethasone according to Miura et al. (2002) and subsequent production of extracellular matrix containing type II collagen, occasionally in combination with human recombinant BMP-2 was used (Caplan et al. 1997, Johnstone et al. 1998). Moreover, Solchaga et al. (2005) described an increase of mitotic activity upon adding the fibroblastic growth factor 2 (FGF-2). Another frequently used procedure is the application of TGF- $\beta 3$ (Mackay et al. 1998, Ahn et al. 2004).

For the present study we formed a new type of MSCs scaffold, which is meeting the following prerequisites: biocompatibility, biodegradability, sufficient porosity for the incorporation of MSCs and simple perioperative manipulation. In this part of the experiment we cooperated with the Institute of Materials Chemistry of the Faculty of Chemistry of the College of Technology in Brno. The scaffolds used in similar studies usually have a gel structure, e.g. collagen gel or PGA scaffold (Grande et al. 1995) and hence do not possess the ideal mechanical properties with regard to the mechanically strained areas of the articular cartilage. Good results were also obtained with scaffolds based on tricalcium phosphate (Guo et al. 2004). The scaffold developed here had a spongy structure and displayed satisfactory mechanical stability and resistance, as well as sufficient porosity to be settled by cells, as was documented by a laboratory test based on confocal microscopy before beginning with the transplantations (Institute of Experimental Medicine, Academy of Sciences of the Czech Republic, Prague).

Our results indicate a higher quality of the newly formed cartilage at the site of iatrogenic defect of the articular surface of the femur of miniature pigs within 16 weeks after surgery, from the point of view of macroscopic, histological and immunohistochemical examination. The newly formed cartilaginous tissue with characteristics of hyaline cartilage, filling the defects of the articular cartilage after transplantation of the scaffold with MSCs (Group A) displayed in $60 \%$ cases a macroscopically smooth surface. Even if the scoring average in the modified evaluation according to O'Driscoll et al. (1988) in Group A was relatively high $(14.7 \pm 3.82$ points), it lags behind the highest possible number of points (24) which characterizes the ideal value of the original hyaline articular cartilage. In experimental studies by Guo et al. (2004) on sheep the average score was $18 \pm 3.38$ but these animals were examined 24 weeks after transplantation. The past study with the rabbit model was terminated 6 and 12 weeks after transplantation and the results were also satisfactory (Grande et al. 1995). We are aware of the possibility of transition of MSCs from 
the seeded scaffold in one part of the knee joint into the non-seeded scaffold in another part of the knee joint. To reduce the number of experimental animals we carried out the transplantation on one knee only. As shown by the results there was evidently no transition in our experiments.

\section{Conclusions}

It follows from the above-said that treatment of iatrogenic lesions of the surface of articular cartilage on femur condyles in miniature pigs after transplantation of mesenchymal stem cells in a composite scaffold based on collagen I containing micro- and nanofibers from chitosan resulted in filling of tissue defects in a hyaline type of cartilage. Lesions treated by implantation of scaffold alone or by micropicking were filled with fibrous cartilage with inferior macroscopic, histological and immunohistochemical parameters.

\section{Conflict of Interest}

There is no conflict of interest.

\section{Acknowledgements}

This work was supported by the Ministry of Education, Youth and Sports of the Czech Republic (NPV II 2B06130) and by the Grant Agency AGEL-MH.

\section{References}

AHN JI, CANALE TS, BUTLER SD, HASTY KA: Stem cell repair of physeal cartilage. J Orthop Res 22: 1215-1221, 2004.

BRITTBERG M, ANDERS L, NILSSON A, OHLSSON C, ISAKSSON O, PETERSON L: Treatment of deep cartilage defects in the knee with autologous chondrocyte transplantation. N Engl J Med 331: 889-895, 1994.

BUTLER DL, SHEARN JT, JUNCOSA N, DRESSLER MR, HUNTER SA: Functional tissue engineering parameters toward designing repair and replacement strategies. Clin Orthop Related Res 427 (Suppl): 190-199, 2004.

CAPLAN AI, ELYADERANI M, MOCHIZUKI Y, WAKITANI S, GOLDBERG VM: Principles of cartilage repair and regeneration. Clin Orthop Relat Res 342: 254-269, 1997.

CHU CR, CONVERY FR, AKESON W, MEYERS M, AMIEL D: Articular cartilage transplantation. Clin Orthop 360: 159-168, 1999.

DETTERLINE J, GOLDSTEIN JL, RUE JPH, BACH BR: Evaluation and treatment of osteochondritis dissecans lesions of the knee. J Knee Surgery 21: 106-116, 2008.

EDWARDS J: Physical characteristics of articular cartilage. Proc Ins Mech Eng 181: 16-24, 1967.

FRIEDENSTEIN AJ, CHAILAKHYAN RK, GERASIMOV UV: Bone marrow osteogenic stem cells: in vitro cultivation and transplantation in diffusion chambers. Cell Tissue Kinet 20: 263-272, 1987.

FRIEDENSTEIN AJ, LATZINIK NV, GORSKAYA YU F, LURIA EA, MOSKVINA IL: Bone marrow stromal colony formation requires stimulation by haemopoietic cells. Bone Miner 18: 199-213, 1992.

GÁl P, NEČAS A, PLÁNKA L, KECOVÁ H, KŘEN L, KRUPA P, HLUČILOVÁ J, USVALD D: Chondrocytic potential of allogenic mesenchymal stem cells transplanted without immunosuppression to regenerate physeal defect in rabbits. Acta Vet Brno 76: 265-275, 2007.

GAO J, YAO JQ, CAPLAN AI: Stem cells for tissue engineering of articular cartilage. J Eng Med 221: 441-450, 2007.

GRANDE DA, SOUTHERLAND SS, MANJI R, PATE DW, SCHWARTZ RE, LUCAS PA: Repair of articular cartilage defects using mesenchymal stem cells. Tissue Eng 1: 345-353, 1995.

GUO X, WANG CH, ZHANG Y, XIA R, HU M, DUAN C, ZHAO Q, DONG L, LU J, SONG YQ: Repair of large articular cartilage defects with implants of autologous mesenchymal stem cells seeded into $\beta$-tricalcium phosphate in a sheep model. Tissue Eng 10: 1818-1829, 2004.

HANNOUCHE D, TERAI H, FUCHS JR, TERADA S, ZAND S, NASSERI BA, PETITE H, SEDEL L, VACANTI JP: Engineering of implantable cartilaginous structures from bone marrow-derived mesenchymal stem cells. Tissue Eng 13: 87-99, 2007.

HOEMANN CD, HURTIG M, ROSSOMACHA E, SUN J, CHEVRIER A, SHIVE MS, BUSCHMANN MD: Chitosan-glycerol hosphate/blood implants improve cartilage repair in ovine microfracture defects. $J$ Bone Joint Surgy (Am) 87: 2671-2687, 2005. 
JACKSON L, JONES DR, SCOTTING P, SOTTILE V: Adult mesenchymal stem cells: differentiation potential and therapeutic applications. J Postgrad Med 53: 121-127, 2007.

JANČÁŘ J, SLOVÍKOVÁ A, AMLER E, KRUPA P, KECOVÁ H, PLÁNKA L, GÁL P, NEČAS A: Mechanical response of porous scaffolds for cartilage engineering. Physiol Res $\mathbf{5 6}$ (Suppl 1): S17-S25, 2007.

JOHNSTONE B, HERING TM., CAPLAN AI, GOLDBERG VM, YOO JU: In vitro chondrogenesis of bone marrowderived mesenchymal progenitor cells. Exp Cell Res 238: 265-272, 1998.

KIM TK, SHARMA B, WILLIAMS CG, RUFFNER MA, MALIK A, MCFARLAND EG, ELISSEEFF JH: Experimental model for cartilage tissue engineering to regenerate the zonal organization of articular cartilage. Osteoarthritis Cartilage 11: 653-664, 2003.

KOLÁČNÁ L, BAKEŠOVÁ J, VARGA F, KOŠŤÁKOVÁ E, LUKÁŠ D, AMLER E, PELOUCH V: Biochemical and biophysical aspects of collagen nanostructure in the extracellular matrix. Physiol Res 56 (Suppl 1): 51-60, 2007.

KRUPA P, KRŠEK P, JAVORNÍK M, DOSTÁL O, SRNEC R, USVALD D, PROKŠ P, KECOVÁ H, AMLER E, JANČÁŘ J, GÁL P, PLANKA L, NEČAS A: Use of 3D geometry modelling of osteochondrosis-like iatrogenic lesions as a template for press-and-fit scaffold seeded with mesenchymal stem cells. Physiol Res $\mathbf{5 6}$ (Suppl 1): S107-S114, 2007.

LANGER R, VACANTI JP: Tissue engineering. Science 260: 920-926, 1993.

LUCAS PA, CALCUTT AF, SOUTHERLAND SS, WILSON A, HARVEY R, WAREJCKA D, YOUNG HE: A population of cells resident within embryonic and newborn rat skeletal muscle is capable of differentiating into multiple mesodermal phenotypes. Wound Repair Regen 3: 457-468, 1995.

MANKIN HJ: The reaction of articular cartilage to injury and osteoarthritis. $N$ Engl J Med 291: 1285-1292, 1974.

MITCHELL N, SHEPARD N: The resurfacing of adult rabbit articular cartilage by multiple perforations through the subchondral bone. J Bone Joint Surg (Am) 58: 230-233, 1976.

MIURA Y, PARVIZI J, FITZSIMMONS JS, O'DRISCOLL SW: Brief exposure to high-dose transforming growth factor-beta1 enhances periosteal chondrogenesis in vitro: a preliminary report. J Bone Joint Surg 84-A: 793799, 2002.

NEČAS A, PLÁNKA L, SRNEC R, RAUŠER P, URBANOVÁ L, LORENZOVÁ J, CRHA M, JANČÁŘ J, GÁL P: Use of biomaterials and stem cells in the treatment of articular cartilage, meniscal, physeal, bone, ligamentous and tendineous defects. Acta Vet Brno 77: 277-284, 2008.

O'DRISCOLL SW, KEELEY FW, SALTER RB: Durability of regenerated articular cartilage produced by free autogenous periosteal graft in major full-thickness defects in joint surfaces under the influence of continuous passive motion. J Bone Joint Surg Am 70: 595-606, 1988.

PITTENGER MF, MACKAY AM, BECK SC, JAISWAL RK, DOUGLAS R, MOSCA JD, MOORMAN MA, SIMONETTI DW, CRAIG S, MARSHAK DR: Multilineage potential of adult human mesenchymal stem cells. Science 284: 143-147, 1999.

PLÁNKA L, NEČAS A, GÁL P, KECOVÁ H, FILOVÁ E, KŘEN L, KRUPA P: Prevention of bone bridge formation using transplantation of the autogenous mesenchymal stem cells to physeal defects: an experimental study in rabbits. Acta Vet Brno 76: 253-263, 2007.

RISBUD MV, SHAPIRO IM, GUTTAPALLI A, DI MARTINO A, DANIELSON KG, BEINER JM, HILLIBRAND A, TODD AJ, ANDERSON GD; VACCARO AR: Osteogenic potential of adult human stem cells of the lumbar vertebral body and the iliac crest. Spine 31: 83-89, 2006.

SHAPIRO F, KOLDE S, GLIMCHER M: Cell origin and differentiation in the repair of full-thickness defects of articular cartilage. J Bone Joint Surg 75A: 532-553, 1993.

SOLCHAGA LA, PENICK K, PORTER JD, GOLDBERG VM, CAPLAN AI, WELTER JF: FGF-2 enhances the mitotic and chondrogenic potentials of human adult bone marrow-derived mesenchymal stem cells. $J$ Cell Physiology 203: 398-409, 2005.

TISATO V, NARESH K, GIRDLESTONE J, NAVARRETE C, DAZZI F: Mesenchymal stem cells of cord blood origin are effective at preventing but not treating graft-versus-host disease. Leukemia 21: 1992-1999, 2007. 
VARGA E, DRŽÍK M, HANDL M, CHLPÍK J, KOS P, FILOVÁ E, RAMPICHOVÁ M, TRČ T, AMLER E: Biochemical characterization of cartilages by a novel approach of blunt impact testing. Physiol Res $\mathbf{5 6}$ (Suppl 1): 61-68, 2007.

WAKITANI S, GOTO T, PINEDA SJ, YOUNG RG, MANSOUR JM, CAPLAN AI, GOLDBERG VM: Mesenchymal cell-based repair of large, full-thickness defects of articular cartilage. J Bone Joint Surgy (Am) 76: 579-592, 1994. 